\title{
THE OCCURRENCE OF Phoenicopterus chilensis MOLINA (AVES, PHOENICOPTERIDAE) IN SÃO PAULO STATE RESERVOIRS
}

\author{
BRANCO, M. B. C., ROCHA, O. and DIAS, M. M. \\ Universidade Federal de São Carlos, Departamento de Ecologia e Biologia Evolutiva, C.P. 676, CEP 13565-905, \\ São Carlos, SP, Brazil \\ (With 1 figure)
}

The chilean flamingo, Phoenicopterus chilensis Molina, 1782 is a species restricted to South America, with a meridional distribution, occurring from central Peru southwards, through the Andes to Tierra del Fuego and extending eastwards to South Brazil and Uruguay (Del Hoyo, 1992). It is a winter visitor in Brazil, being observed in Rio Grande do Sul, from April to September, appearing at Lagoa do Peixe, a coastal lagoon and adjacent beaches, in large flocks (Sick, 2001). In an exceptional occurrence, it has also been recorded in Santa Catarina (Sick et al., 1980). According to those authors, the closest permanent colony is located at Santa Fé, Argentina. At present, according to Bucher et al. (2000), Mar Chiquita Lake, in Cordoba, Argentina, is among the most important nesting areas for $P$. chilensis.

Flamingoes live preferentially in large, shallow, brackish or salt water lagoons, being abundant in places where fish competition for benthic invertebrates or plankton is absent or of low intensity (Sick, 2001). They feed mainly on crustaceans (copepods, cladocerans, ostracods and others), aquatic insects and snails (Del Hoyo, 1992). According to Belton (1994), the bodies of water used by P. chilensis in Rio Grande do Sul are freshwater or brackish habitats, with sand and mud bottoms.

During an inventory of water birds at Tietê River Reservoirs, the occurrence of one individual of $P$. chilensis was observed at Bariri Reservoir on 8 June 2001, at the entrance of the Bauru River $\left(22^{\circ} 14^{\prime} 53^{\prime \prime} \mathrm{S}, 48^{\circ} 48^{\prime} 2.1^{\prime \prime} \mathrm{W}\right)$. The specimen was observed feeding in the shallow littoral zone $(0.30$ $\mathrm{m}$ deep). Other birds were also present, some in large numbers, among them, 8 Bubulcus ibis (Ardeidae), 1 Mycteria americana (Ciconiidae), 48 Gallinula chloropus (Rallidae), 90 Himantopus himantopus (Recurvirostridae) and 11 Tachycineta leucorrhoa (Hirundinidae). Another specimen was observed at Salto Grande Reservoir (22 $44^{\prime} \mathrm{S}$ and $47^{\circ} 20^{\prime} \mathrm{W}$ ) on September 27 in similar littoral areas. Previous sightings of flamingoes at this reservoir occurred a few months earlier by C. Lopes-Ferreira (personal communication). Fig. 1 shows the known species geographic distribution according to Del Hoyo (1992) and also the localities where the sightings occurred. P. chilensis is not common at water bodies in São Paulo State.

Both Bariri and Salto Grande Reservoirs belong to the Tietê River hydrographic basin and are very eutrophic. Pamplin (1999) found high densities of benthic invertebrates in Salto Grande Reservoir, with dominance of Oligochaeta which represents more than $50 \%$ of the total numerical density.

The sighting of the flamingo in Tietê reservoirs may represent an extension of its geographic range to exploit new feeding localities, although by few individuals, probably separated from the flock. According to Margalef (1983) man-made lakes can provide new feeding habitats for aquatic birds, even inducing changes in migratory paths of some species. In Spain, Carbonell \& MuñozCobo (1976) and Garcia et al. (1980) observed that the creation of a large number of reservoirs in the interior of the country led to the restructuring of aquatic bird migratory routes. Birds that previously migrated close to the coast now go through the country, particularly the anatids. A similar process may be occurring for the flamingo. It seems therefore relevant to report the appearance of $P$. chilensis in São Paulo State Reservoirs. 


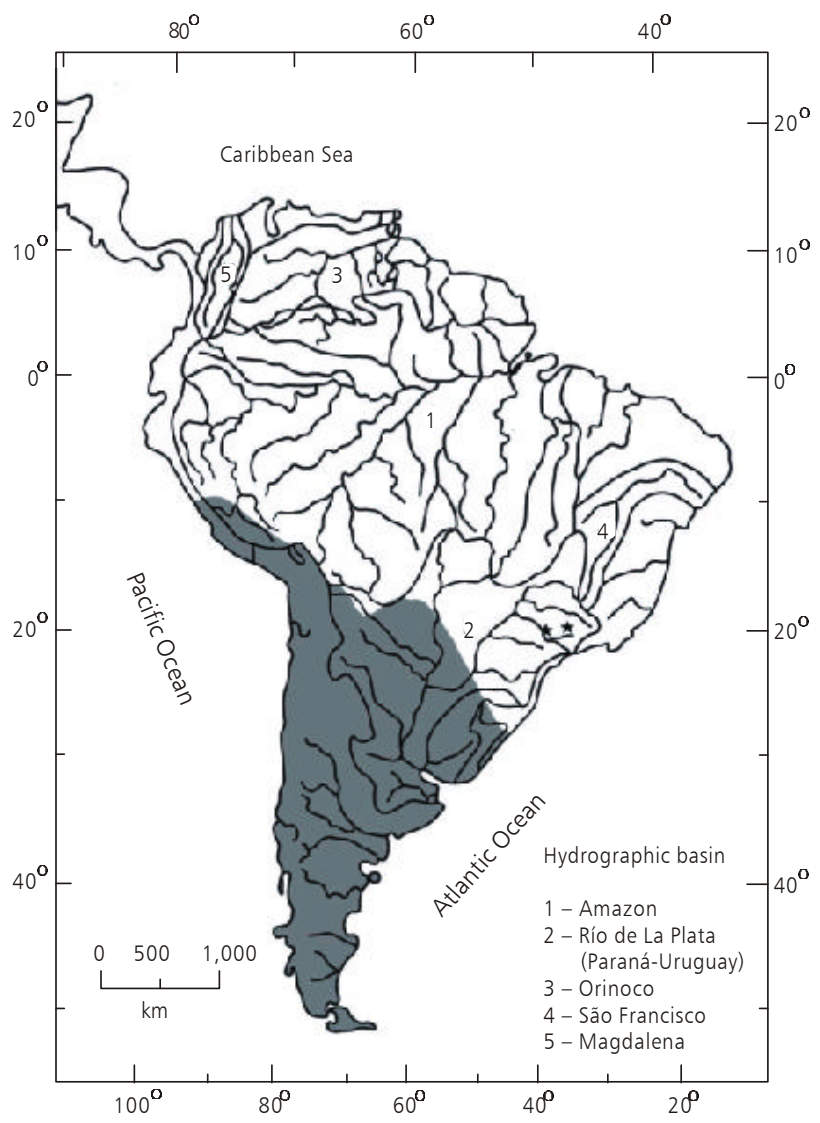

Fig. 1 - South American main hydrographic basins and geographic distribution of the Phoenicopterus chilensis, the chilean flamingo (according to Del Hoyo, 1992), and the new sighting localities in São Paulo State (Bariri and Salto Grande reservois) as indicated by stars.

Acknowledgments - The authors thank the Brazilian Ministry of Environment (MMA), the Brazilian National Research Council (CNPq), the Bank for Inter-American Research Development (BIRD) and The Global Environmental Facilities (GEF), sponsors of the Program of Biodiversity (Probio).

\section{REFERENCES}

BELTON, W., 1994, Aves do Rio Grande do Sul. Distribuição e biologia. T. T. Roberts (trad.). Ed. Unisinos, São Leopoldo, 584p.

BUCHER, E. H., ECHEVARRIA, A. L., JURI, M. J. \& CHANI, V. M., 2000, Long-term survey of chilean flamingo breeding colonies on Mar Chiquita Lake, Córdoba, Argentina. Waterbirds, special publ, 23(1): 114-118.

CARBONNEL, M. \& MUÑOZ-COBO, J., 1976, Censo español de aves acuáticas. Ardeola, 25: 3-46. Enero.

DEL HOYO, V., 1992, Order Phoenicopteriformes, Family Phoenicopteridae (flamingos). pp. 507-526, In: V. Del Hoyo, A. Elliot \& V. Sargatai (eds.), Handbook of the Birds of the World. Vol. 1. Ostrich to ducks. Lynx Edicions, Barcelona, 696p.
GARCIA, L., AMATOZ-COBO, J. A. \& SANCHEZ, A. 1980, Resultados de los censos de aves acuáticas en Andalucia occidental durante el invierno de 1978-1979. Acta Vertebrata, 7: 19-27.

MARGALEF, R., 1983, Limnologia. 1.ed. Ediciones Omega Barcelona, 1010p.

PAMPLIN, P. A. Z., 1999, Evaluation of the environmental quality of Americana reservoir (SP, Brazil) with emphasis on benthic macroinvertebrate community and ecotoxicological parameters. MSc. Dissertation University of São Paulo, School of Engineering of São Carlos, 88p. (In Portuguese.)

SICK, H., ROSÁRIO, L. A. \& AZEVEDO, T. R., 1980, Aves do Estado de Santa Catarina, Sellowia. Vol. 1, Zoologia.

SICK, H., 2001, Ornitologia Brasileira. Edição revista e ampliada por José Fernando Pacheco. Editora Nova Fronteira, Rio de Janeiro, 862p. 